\title{
Investigating the Effect of Supplementary Feeding on Carbohydrate Composition and Quantity of Royal Jelly
}

\author{
Dimitrios Kanelis, Chrysoula Tananaki*, Vasilios Liolios, Maria-Anna Rodopoulou, \\ Georgios Goras, Nikolia Argena, Andreas Thrasyvoulou
}

Laboratory of Apiculture-Sericulture, Aristotle University of Thessaloniki, Aristotle Farm, Thermi, Greece

Email: ^tananaki@agro.auth.gr

How to cite this paper: Kanelis, D., Tananaki, C., Liolios, V., Rodopoulou, M.-A., Goras, G., Argena, N. and Thrasyvoulou, A. (2018) Investigating the Effect of Supplementary Feeding on Carbohydrate Composition and Quantity of Royal Jelly. Open Journal of Applied Sciences, 8, 141-149. https://doi.org/10.4236/ojapps.2018.84011

Received: March 7, 2018

Accepted: April 21, 2018

Published: April 24, 2018

Copyright $\odot 2018$ by authors and Scientific Research Publishing Inc. This work is licensed under the Creative Commons Attribution International License (CC BY 4.0).

http://creativecommons.org/licenses/by/4.0/

(c) (i) Open Access

\begin{abstract}
One of the main practices followed by beekeepers during the production of royal jelly (RJ) is the artificial sugar feeding. In this study, the effect of carbohydrate supplementary feeding on the composition of the three main sugars (fructose, glucose, sucrose) and on the final quantity of the product was explored using one-way ANOVA and non-parametric tests. Also, the correlations among the parameters were examined. The average yield per colony for non-supplemented colonies (Group A) was $12.8 \mathrm{~g}$, while the average content of fructose, glucose and sucrose was $4.32 \%, 3.78 \%$, and $0.04 \%$, respectively. For the colonies fed at the grafting day one time (Group B), these values were $12.76 \mathrm{~g}, 3.11 \%, 3.19 \%$ and $3.71 \%$, and for the colonies fed from the insertion until the collection day (Group C), $12.81 \mathrm{~g}, 3.05 \%, 3.12 \%$ and $3.54 \%$ respectively. It should also be noted that the sucrose content in all samples from supplemented colonies was found greater than $1.97 \%$. The statistical tests highlighted the impact of artificial feeding on fructose and glucose contents, while the produced quantity remained uninfluenced. Finally, the Spearman (rho) coefficient test showed statistically significantly negative correlation between the monosaccharides (fructose, glucose) and sucrose.
\end{abstract}

\section{Keywords}

Royal Jelly, Feeding Experiment, HPLC, Sugars, ANOVA

\section{Introduction}

Royal jelly (RJ), named by the Swiss botanist Francois Hubber in 1788 [1], is a creamy, white and viscous natural secretion from hypopharyngeal and mandi- 
bular glands of honeybees [2]. It is secreted by young worker bees [3] [4] [5] to feed the queen throughout her life and the sexually immature females for only the first three days. It contains about $60 \%$ to $70 \%$ moisture [6] [7] [8], $9 \%$ to $18 \%$ crude protein, $10 \%$ to $19 \%$ main sugars [9] [10] [11], $2.2 \%$ to $8.0 \%$ total lipids [7] [11], $0.8 \%$ to $3 \%$ ash [9] [12] and varieties of other nutrients including amino acids, minerals and vitamins [13].

Besides honey, RJ can greatly enhance the beekeeper's income. Its price is high, the yield is relatively stable even under adverse climatic conditions and the consumers' interest in the product is increasing. Although the future prospectus of RJ trade is growing, problems appear in its marketing mainly because no legislative framework exists to support its authenticity and quality [14]. The adoption of RJ legislation requires knowledge about the chemical synthesis of the product and the factors that may affect its composition. According to Sabatini et al. [12], the chemical synthesis of RJ varies considerably due to the different sampling procedures, the production conditions and the diversity of the analytical methods. Furthermore, Takenaka et al. [15], Chen \& Chen [16] and Kanelis [17] noted other factors as well, such as the storage conditions, which considerably alter the sugar composition of RJ.

Not only the storage conditions but also the beekeeping practices are mentioned to affect RJ's carbohydrate composition [18]. Yet, the scientific findings do not clarify whether feeding affects the chemical synthesis of the product because some authors claim that it causes changes [19] [20] [21] and some others that it does not [22] [23]. Beekeepers believe that the feeding of bees during RJ production, stimulate workers to increase the quantity of RJ [20] [21] but this notion has not been scientifically proved [21].

The aim of the present study was to investigate through analysis of variance (ANOVA) the impact of the feeding practice that is commonly used by the beekeepers during the production of RJ, on its final quantity and main carbohydrate composition. The results deriving from this useful statistical tool will provide eventually sufficient information about the practices during RJ's production.

\section{Materials and Methods}

\subsection{Sampling and RJ Production}

Sixty artificial queen cells were grafted with 48 -h-old larvae and were placed in queenless colonies sited at the University farm of Aristotle University of Thessaloniki, Greece. The sample production started at June of 2016 and it lasted almost seven weeks. The 48-h-old larvae were obtained from unsealed brood of other bee colonies from the same apiary. Every third day, the grafted cells were removed, replaced by another 60 cells, to complete four consecutive graftings and the RJ was collected. The RJ from the accepted cells of each grafting was mixed to form the experimental samples. The queenless colonies received one comb of sealed brood every six days to discourage the development of ovaries of worker-bees. The RJ samples were stored at $-18^{\circ} \mathrm{C}$ until their analysis. 


\section{Feeding Experiment}

Royal jelly samples were produced from six queenless bee colonies that were divided into three equal groups that received the following treatments:

Group A: The colonies were not provided with any syrup before or during the study.

Group B: The colonies were provided with $500 \mathrm{~mL}$ sugar syrup (1:1) only the grafting day.

Group C: The colonies were fed every day, from the grafting day until the collection day with $500 \mathrm{~mL}$ sugar syrup (1:1).

Feeding of groups B and C started ten days before the main experiment and involves everyday provision of $500 \mathrm{~mL}$ sugar syrup (1:1), which contained $1 \mathrm{~kg}$ of sugar and $1 \mathrm{~L}$ of water. Totally 72 samples were produced, 24 in each group.

\subsection{Carbohydrate Determination}

Glucose, fructose and sucrose of RJ were determined using the HPLC-RID technique. Samples of RJ were mixed with the solutions Carrez I (150 mg.mL $\mathrm{m}^{-1}$ ) $\left(\mathrm{C}_{6} \mathrm{FeK}_{4} \mathrm{~N}_{6}{ }^{*} 3 \mathrm{H}_{2} \mathrm{O}\right)$ (Fluka, Germany) and Carrez II (300 $\left.\mathrm{mg} \cdot \mathrm{mL}^{-1}\right)$ $\left[\left(\mathrm{CH}_{3} \mathrm{COO}\right)_{2} \mathrm{Zn}^{\star} 2 \mathrm{H}_{2} \mathrm{O}\right]$ (Merck, Germany) and transferred in volumetric flasks. The flask was filled with mixture of methanol (Chem-Lab, Belgium)/water $(25: 75, \mathrm{v} / \mathrm{v})$ until the final volume of $5 \mathrm{~mL}$. The solution was filtered through a disposable syringe filter $(0.45 \mu \mathrm{m})$ before the injection. The sugars were separated on a Zorbax Carbohydrate Analysis Column (4.6 mm ID $\times 150 \mathrm{~mm} \times 5$ $\mu \mathrm{m})$ using as mobile phase a mixture of acetonitrile (Sigma-Aldrich, USA)/water $(80: 20, \mathrm{v} / \mathrm{v})$ at a flow rate of $1.3 \mathrm{~mL} \cdot \mathrm{min}^{-1}$ and injection volume at $10 \mu \mathrm{L}$. The detection was achieved using a refractive index detector (RID).

\subsection{Statistical Analysis}

The comparisons among the different groups regarding the quantity of produced RJ and carbohydrate composition were completed by using the one-way analysis of variance (ANOVA) for normal populations and the non-parametric test Kruskal-Wallis for the parameters that did not have a normal distribution. The normality of the data was checked by creating probability plots. Finally, in order to examine the correlation among the parameters, for normal populations, the parametric correlation coefficient of Pearson ( $r$ ) was calculated while for non-normal populations the non-parametric coefficient of Spearman (rho) was used. The statistical analyses were performed using the Minitab Ink statistics software (ver. 17) and the level of significance was set at $\alpha \leq 0.05$.

\section{Results and Discussion}

Analysis of variance (ANOVA) is a statistical procedure used in this research to determine whether there are significant differences between the three group means. The probability plots showed that all the parameters except sucrose followed a normal distribution (Figure 1). Thus, for fructose, glucose and RJ quantity the one-way ANOVA was considered as appropriate for the statistical 

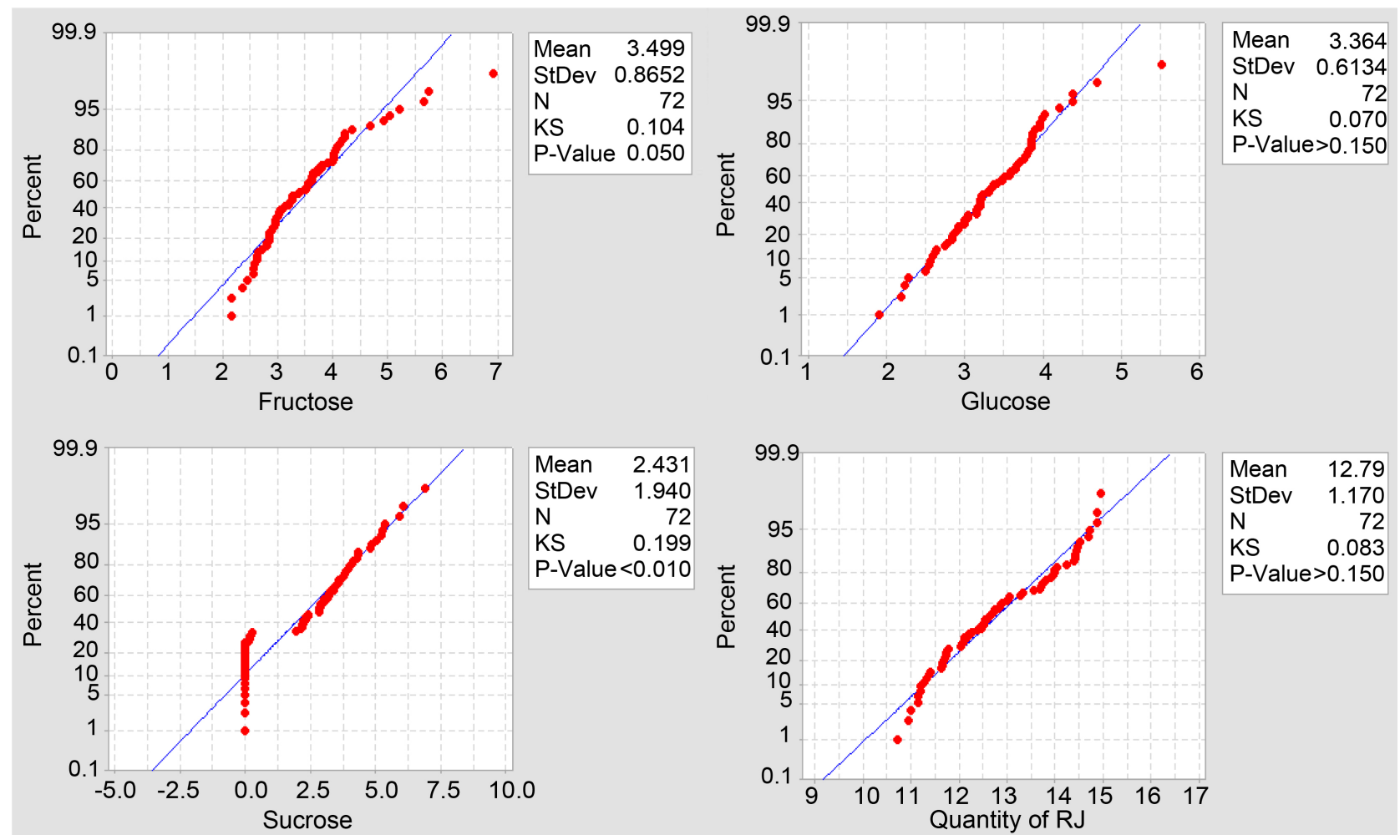

Figure 1. Probability Plots of main sugars and final quantity of RJ in all groups.

process of the data. On the contrary, in case of sucrose, which did not follow the normal distribution, the nonparametric test Kruskal-Wallis was applied. For the above reason, the means for fructose, glucose and RJ quantity were separated by Duncan's multiple range test, while the means regarding the sucrose parameter were separated by Mann-Whitney's Test, at the same significant level (Table 1 and Table 2).

Both tests showed statistically significant differences among the groups for all the studied parameters $\left(\mathrm{p}_{\max }=0.000\right)$, except the RJ's quantity per colony ( $\mathrm{p}=$ 0.990) (Table 1). Indeed, the group without artificial sugar feeding (Group A) compared with the other two (Groups B and C), had statistically significantly higher concentrations of fructose and glucose and statistically significantly lower sucrose content (Table 2 and Figure 2). Consequently, the statistical analyses suggest that sugar feeding affects the carbohydrate composition of the final product, whereas the quantity seems to be independent. Additionally, regarding the correlation among the parameters, it was found a statistically significant positive correlation between fructose and glucose $(r=0.661, p=0.000)$, while between fructose or glucose and sucrose, the correlation was statistically significant negative $\left(\mathrm{rho}_{\min }=-0.595, \mathrm{p}=0.000\right)$ (Table 3). Indeed, in low concentrations of sucrose, the concentrations of glucose and fructose were high and the opposite.

The findings of this study are in agreement with those of Daniel and Casabianca [18], who referred that fructose and glucose contents decreased in the presence of artificial feeding, while sucrose increased. On the other hand, 
Table 1. The one way ANOVA and the Kruskal-Wallis table presenting sum of squares, degrees of freedom (df), mean square and F-test for the parameters fructose, glucose and RJ quantity.

\begin{tabular}{ccccccc}
\hline One way ANOVA & Parameter & $\begin{array}{c}\text { Sum of Squares } \\
\text { (Between groups) }\end{array}$ & df & $\begin{array}{c}\text { Mean } \\
\text { Square }\end{array}$ & F & Sig. \\
\hline & Fructose & 24.827 & 2 & 12.414 & 30.244 & 0.000 \\
& Glucose & 6.350 & 2 & 3.175 & 10.758 & 0.000 \\
& RJ Quantity & 0.028 & 2 & 0.014 & 0.010 & 0.990 \\
\hline \multirow{2}{*}{ Kruskal-Wallis } & Parameter & Chi-Square & df & & & Asym. \\
& Sucrose & 48.288 & 2 & & & Sig. \\
\hline & & & & & & \\
\hline
\end{tabular}

Table 2. Mean values and standard deviations of fructose, glucose, sucrose and RJ quantity per colony.

\begin{tabular}{|c|c|c|c|c|}
\hline Group $(\mathrm{n}=24)$ & $\begin{array}{l}\text { Fructose }^{\star} \\
(\%)\end{array}$ & $\begin{array}{c}\text { Glucose* } \\
(\%)\end{array}$ & $\begin{array}{l}\text { Sucrose }^{* *} \\
(\%)\end{array}$ & $\begin{array}{c}\mathrm{RJ} \\
\text { quantity/colony* (g) }\end{array}$ \\
\hline Unfed colonies (A) & $4.33 \pm 0.89^{\mathrm{a}}$ & $3.78 \pm 0.59^{\mathrm{a}}$ & $0.04 \pm 0.08^{\mathrm{b}}$ & $12.78 \pm 1.10^{\mathrm{a}}$ \\
\hline $\begin{array}{l}\text { Colonies fed during } \\
\text { grafting (B) }\end{array}$ & $3.11 \pm 0.50^{\mathrm{b}}$ & $3.19 \pm 0.54^{\mathrm{b}}$ & $3.71 \pm 1.12^{\mathrm{a}}$ & $12.76 \pm 1.16^{\mathrm{a}}$ \\
\hline Colonies fed every day (C) & $3.05 \pm 0.43^{\mathrm{b}}$ & $3.12 \pm 0.49^{\mathrm{b}}$ & $3.54 \pm 1.18^{\mathrm{a}}$ & $12.81 \pm 1.29^{\mathrm{a}}$ \\
\hline
\end{tabular}

${ }^{\star}$ In each column, values followed by different letters were significantly different $(\alpha=0.05$, Duncan's multiple range test). ${ }^{* *}$ In each column, values followed by different letters were significantly different $(\alpha=0.05$, Mann-Whitney's multiple range test).

Table 3. Pearson (r) and Spearman (rho) correlation coefficients among sugars and quantity parameters.

\begin{tabular}{|c|c|c|c|c|}
\hline & Fructose & Glucose & Sucrose & $\begin{array}{l}\text { RJ quantity } \\
\text { per colony }\end{array}$ \\
\hline Fructose $^{1}$ & - & $0.661^{*}$ & $-0.595^{*}$ & 0.027 \\
\hline Glucose $^{1}$ & $0.661^{*}$ & - & $-0.488^{*}$ & 0.108 \\
\hline Sucrose $^{2}$ & $-0.595^{\star}$ & $-0.488^{\star}$ & - & 0.011 \\
\hline RJ quantity per colony ${ }^{1}$ & 0.027 & 0.108 & 0.011 & - \\
\hline
\end{tabular}

${ }^{*}$ Correlation is significant at the 0.05 level (2-tailed). ${ }^{1}$ Pearson correlation. ${ }^{2}$ Spearman correlation.

Sesta et al. [24] and Balkanska et al. [25] reported that there was not any effect of supplementary sugar feeding on the content of RJ's three main sugars. Despite their decrease, the concentrations of fructose and glucose determined in the present research were in the same levels with the respective concentrations found by other authors [18] [24].

In the study of Daniel and Casabianca [18], the lower value of sucrose concentration in the samples produced under feeding conditions was $0.1 \%$ and the higher $5.1 \%$. However, over the half of their samples derived from the feeding experiment, had sucrose concentration between $0.1 \%$ and $0.5 \%$, which is the same with the sucrose concentration range found in the samples that we produced from colonies without sugar feeding. In another study, the range of sucrose 


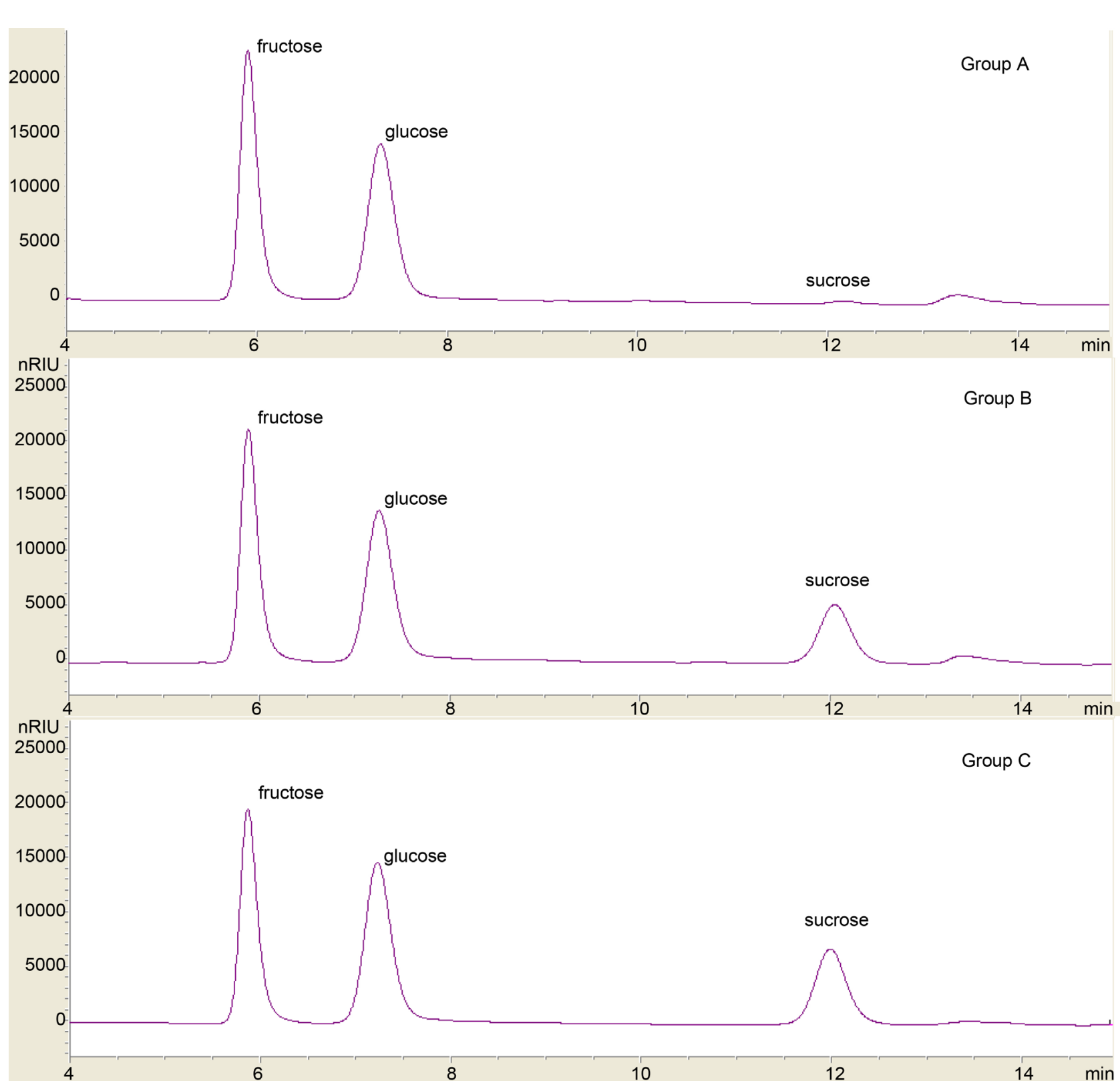

Figure 2. Chromatograms of the three main sugars of the three different groups.

in RJ from colonies supplied with syrup was between no detectable and $2.1 \%$ [24]. In our research, the range of sucrose in RJ from every day feeding experiments was $2.13 \%$ to $6.90 \%$ and from one-day feeding (only the day of grafting) was $1.97 \%-5.94 \%$. The RJ samples from unfed colonies had maximum sucrose $0.29 \%$. Thus, this experiment supports stronger the notion that the artificial sugar feeding affects the concentration of sucrose.

The majority of authors and the general opinion of beekeepers support that supplementary feeding increases the final quantity (yield) of the produced RJ per grafting. According to Şahinler et al. [26], the acceptance of artificial queen cells and the produced quantity were increased using feeding supplements. On the other hand, Weiss [21] noted that stimulative feeding does not influence the 
acceptance or the quantity when given just before and during the period of RJ production. The results of this study are in agreement with the findings of Weiss [21], as we proved that the final quantity of the produced RJ was unaffected. However, as mentioned above, the stimulative supplements are necessary in order to stimulate the queen's egg laying. Moreover, in this way, many young workers, which are responsible for the RJ production, are hatched and the final quantity of RJ can be kept stable.

\section{Conclusion}

Feeding sugar in syrup form is the most popular method in the production of RJ because it helps the queens to lay eggs at high levels. According to the results of this study, the quantity of the produced RJ does not increase due to artificial sugar feeding, instead, it remains stable. We also found that the composition of the three main sugars in RJ changed significantly in the presence of artificial sugar feeding in the bee colony, during the production. The ANOVA and the coefficient tests were used to compare the results. Specifically, fructose and glucose decreased in the samples produced from fed colonies whereas sucrose increased. These findings have a practical value and are important to beekeepers that produce RJ. However, further research should be done on feeding experiments with the purpose to minimise the impact of the artificial feeding on the product of RJ.

\section{References}

[1] Crane, E. (1990) Bees and Beekeeping, Science, Practice and World Resources. Heinemann Professional Publishing Ltd, Oxford, London.

[2] Willson, R.B. (1955) Royal Jelly: A Review. Part 1-The Scientific Aspects. American Bee Journal, 95, 16-19.

[3] Patel, N.G., Haydak, M.H. and Gochnauer, T.A. (1960) Electrophoretic Components of the Proteins in Honey-Bee Larval Food. Nature, 186, 633-634. https://doi.org/10.1038/186633a0

[4] Haydak, M.H. (1970) Honey Bee Nutrition. Annual Review of Entomology, 15, 143-156. https://doi.org/10.1146/annurev.en.15.010170.001043

[5] Lensky, Y. and Rakover, Y. (1983) Separate Protein Body Compartments of the Worker Honeybee (Apis mellifera L.). Comparative Biochemistry and Physiology, 66, 185-193. https://doi.org/10.1016/0305-0491(83)90104-9

[6] Sesta, G. and Lusco, L. (2008) Refractometric Determination of Water Content in Royal Jelly. Apidologie, 39, 225-232. https://doi.org/10.1051/apido:2007053

[7] Popescu, O., Marghitas, L.A.L. and Dezmirean, D. (2008) A Study about Physicochemical Composition of Fresh and Lyophilized Royal Jelly. Zootehnie si Biotehnologii, 41, 328-332.

[8] Szczęsna, T., Rybak-Chmiellewska, H., Was, E. and Skubida, P. (2009) Water Determination in Bee Products Using the Karl Fischer Titration Method. Journal of Apicultural Science, 53, 49-56.

[9] Karaali, A., Meydanoglou, F. and Eke, D. (1987) Studies on Composition, Freeze-Drying and Storage of Turkish Royal Jelly. Journal of Apicultural Research, 3, 182-185. 
[10] Sesta, G. (2006) Determination of Sugars in Royal Jelly by HPLC. Apidologie, 37, 84-90. https://doi.org/10.1051/apido:2005061

[11] Garcia-Amoedo, L.H. and Almeida-Muradian, L.B. (2007) Physicochemical Composition of Pure and Adulterated Royal Jelly. Química Nova, 30, 257-259. https://doi.org/10.1590/S0100-40422007000200002

[12] Sabatini, A.G., Marcazzan, G.L., Caboni, M.F., Bogdanov, S. and Almeida-Muradian, L.B. (2009) Quality and Standardisation of Royal Jelly. Journal of ApiProduct and ApiMedical Science, 1, 16-21. https://doi.org/10.3896/IBRA.4.01.1.04

[13] Pina, A., Begou, O., Kanelis, D., Gika, H., Kalogiannis, S., Tananaki, Ch., Theodoridis, G. and Zotou, A. (2018) Targeted Profiling of Hydrophilic Constituents of Royal Jelly Byhydrophilic Interaction Liquid Chromatography-Tandem Massspectrometry. Journal of Chromatography A, 1531, 53-63. https://doi.org/10.1016/j.chroma.2017.11.019

[14] Kanelis, D., Tananaki, Ch., Liolios, V., Dimou, M., Goras, G., Rodopoulou, M.A., Karazafiris, E. and Thrasyvoulou, A. (2015) A Suggestion for Royal Jelly Specifications. Archives of Industrial Hygiene and Toxicology, 66, 275-284. https://doi.org/10.1515/aiht-2015-66-2651

[15] Takenaka, T., Yatsunami, K. and Echigo, T. (1986) Changes in Quality of Royal Jelly during Storage. Nippon Shokuhin Kögyō Gakkaishi, 33, 1-7. https://doi.org/10.3136/nskkk1962.33.1

[16] Chen, C. and Chen, S. (1995) Changes in Protein Components and Storage Stability of Royal Jelly under Various Conditions. Food Chemistry, 54, 195-200. https://doi.org/10.1016/0308-8146(95)00031-D

[17] Kanelis, D. (2017) Factors That Affect the Physicochemical Characteristics of Honeybees' Royal Jelly (Apis mellifera L.). PhD Dissertation, Laboratory of Apiculture-Sericulture, Aristotle University of Thessaloniki, Thessaloniki.

[18] Daniele, G. and Casabianca, H. (2012) Sugar Composition of French Royal Jelly for Comparison with Commercial and Artificial Sugar Samples. Food Chemistry, 134, 1025-1029. https://doi.org/10.1016/j.foodchem.2012.03.008

[19] Inoue, T. and Inoue, A. (1964) The World Royal Jelly Industry: Present Status and Future Prospects. Bee World, 45, 59-69. https://doi.org/10.1080/0005772X.1964.11097045

[20] Chen, S., Su, S. and Lin, X. (2002) An Introduction to High Yielding Royal Jelly Production Methods in China. Bee World, 83, 69-77. https://doi.org/10.1080/0005772X.2002.11099543

[21] Weiss, K. (1983) The Influence of Rearing Condition on Queen Development. In: Ruttner, F., Ed., Queen Rearing, Apimondia Publishing House, Bucharest, 83-148.

[22] Wytrychowski, M., Daniele, G. and Casabianca, H. (2012) Combination of Sugar Analysis and Stable Isotope Ratio Mass Spectrometry to Detect the Use of Artificial Sugars in Royal Jelly Production. Analytical and Bioanalytical Chemistry, 403, 1451-1456. https://doi.org/10.1007/s00216-012-5934-6

[23] Daniele, G., Wytrychowski, M., Batteau, M., Guibert, S. and Casabianca, H. (2011) Stable Isotope Ratio Measurements of Royal Jelly Samples for Controlling Production Procedures: Impact of Sugar Feeding. Rapid Communications in Mass Spectrometry, 25, 1929-1932. https://doi.org/10.1002/rcm.5070

[24] Sesta, G., Persano Oddo, L., Nisi, F. and Ricci, L. (2006) Effects of Artificial Sugar Feeding on Sugar Composition of Royal Jelly. Apiacta, 41, 60-70. 
[25] Balkanska, R., Zhelyazkova, I., Ignatova, M. and Kashamov, B. (2013) Effect of Supplementary Honey and Artificial Sugar Feeding of Bees on the Composition of Royal Jelly. Agricultural Science and Technology, 5, 335-338.

[26] Şahinler, N., Gül, A. and Şahin, A. (2005) Vitamin E Supplement in Honey Bee Colonies to Increase Cell Acceptance Rate and Royal Jelly Production. Journal of Apicultural Research, 44, 58-60. https://doi.org/10.1080/00218839.2005.11101149 